\title{
Gender Differences in Ethical Sensitivity in the Indian Business Context
}

\author{
Arun Antony Chully*
}

\section{Abstract}

Ethical businesses can bring prosperity to society without creating harm to people or environment. Most of the huge corporate scams and frauds involve men in comparison to women. Many studies have found that women at the top management positions in businesses are more ethical than their male counterparts. In the context of growing number of women entering into the corporate world and decisionmaking positions of businesses, this study explores the question whether the ethical sensitivity of women is higher than that of men in the Indian context. Sample consists of 258 MBA students from 6 different business schools in the city of Bangalore. Study has used an adapted version of business ethical vignettes created by Longenecker, J. G., McKinney, J. A., \& Moore, C. W. (1989). The results showed that the self-reported score of ethical sensitivity of female students is higher than that of their male counterparts. The study has significant implications in terms of promoting more women to the top positions of businesses which might result in more ethical business environment and probably a better and sustainable future for our country.

Keywords: Ethical sensitivity, Business ethics, Gender difference

\section{Introduction}

Businesses are the lifeblood of any society. The economy of a country which contributes to the quality of life of its citizens is

*Christ Institute of Management, Lavasa, India; frarun@cimlavasa.in 
driven by the thriving businesses of that country. India as a nation has become a force to reckon with post 1991 liberalisation policies when it unleashed the entrepreneurial spirits of many Indians. Since the second half of the 1990s, the economy has consistently posted a growth rate of $7.5 \%$ or more, about twice the rate of the years between Independence in 1947 and liberalization in 1991. Economic liberalization has greatly affected Indian attitudes toward money, business, development and politics, and opened doors for the ambitions of millions of young people. A laggard in the world for much of the 20th century, India now confidently inhabits the $21^{\text {st }}$ century (Choudhary, 2011).

From a different angle, businesses can create destruction and havoc in the lives of people and society as well. Along with the rise of corporations in improving the lives of individuals and communities, their unethical practices in search of maximising the profits have created great negative impacts on the society at large. Financial manipulation of Enron and Worldcom, people exploitation and human rights abuse of Nike, Monsanto and Chevron are a few examples of widely publicized business scandals. When businesses increase rich-poor divide by accumulation of wealth into the hands of a few, exploit the natural resources for increasing the bottom-line, pollute the environment uncontrollably and fail to ensure safe and healthy working conditions, they are doing great harm to the country and its people. The Indian story is not any different. Income inequality has reached unprecedented levels and corruption in post-liberalization India has reached unbelievable levels. In a single scam involving the deliberate undervaluing of cell phone licenses, India's corporate honchos, in collusion with bureaucrats and politicians, cheated the government of billions of dollars (Pal, 2012).

The tremendous power businesses wield can be channelized for the good of all only when businesses are led by leaders of high ethics and integrity. In India, we have icons like Narayan Moorthy and others who have proved that it is possible to build business empires ethically. The massive businesses they built have helped millions to find their livelihood and climb the social ladder. But the depressing fact is that such business leaders with high standards of ethics are only a handful. How do we have more of them at the 
decision making levels is an important concern that is yet to be addressed.

Today we see more and more women entering into businesses and job market unlike the past and the trend is on the rise (Pianin, 2017). But at the same time, there is a lot of discrimination with regard to gender at the workplace. Women earned only 83 percent of what men earned working comparable hours in 2015, according to a Pew Research Center study. Women must work on an average an additional 44 days to earn the same annual salary as their male counterparts. Even in job categories such as child care that are predominantly occupied by women, they still only earn about 95 percent of men's wages for performing the same jobs (Wolfe, 2017). On a more specific note, in 2012, of the Fortune 500 companies CEOs, 96.4\% were men and only $3.6 \%$ were women (Burns \& Krehely, 2013). But a more interesting conversation is to see if more women in the workplace mean a workplace becomes a more ethical workplace. Many studies in the west have found that women at the top management positions in businesses are found to be more ethical than their male counterparts (Wen, 2013). Many researchers have found women to have higher, more steadfast ethical standards and to act more ethically than men in a variety of situations (Kray, Kennedy, \& Ku, 2017). These findings are very reassuring for both businesses and society at large.

In this study, I would like to explore the question whether there is a difference with regard to ethical sensitivity across gender in the Indian context. Though similar studies are done in other countries, there is a dearth of such documented research in India. This study is significant to consider possibilities of having more women in the decision making positions in corporate houses so that businesses contribute more effectively to the sustainable future of our country.

\section{Ethical Sensitivity}

In order to exercise ethical choices in a business situation, one needs to recognize the presence of an ethical issue. According to Hunt and Vitell (1992), "When placed in a decision-making situation having an ethical component, some people never recognize that there is an ethical issue involved at all" (p. 781). Similarly, Rest (1986) contends that differences among people in 
their tendency to recognize ethical issues can be striking: " Before it occurs to some people that a moral issue may be involved, they have to see the blood flowing. Other people are so supersensitive that every act, work or grimace takes on momentous moral implications" (p. 6). Unethical choices in the business context are often a result of failure to discern the ethical dimensions of the choices. Ethical sensitivity is the ability to recognize that there is an ethical issue involved in a specific situation.

\section{Gender and Ethical Sensitivity}

The role of demographic variables in influencing ethical sensitivity has been a topic of considerable interest. Among different variables, one of the most researched would be the issue of gender and its relationship to ethical perceptions and behaviours. However, there is no conclusive outcome in terms of identifying whether males and females differ in their ethical orientations and behaviours. There are opposing results coming out of different research on this theme. Irrespective of the varying ideas, it seems that many scholars, throughout history, have asserted that morality is gendered (Tronto, 1993). In his path-breaking research and theory on Cognitive Moral Development, Kohlberg (1976) argued that most men eventually reach Stage 4 whereas most women only reach Stage 3. Though the theory of cognitive moral development was well received, it has been criticized for being sexist (Gilligan, 1982). Gilligan argues that the conclusions arrived by Kohlberg is based on a sample of 84 boys and hence it is not representative of the population and cannot be generalized particularly on women. Gilligan suggests that males and females have markedly distinct moral orientations. Women speak in a "different voice" and accordingly they operate at a different moral space than men. According to this argument, one has to distinguish between an ethic of justice and an ethic of care. Men tend to stress justice while women's "sense of integrity appears to be entwined with an ethic of care" (p. 171). Though criticized (Walker, 1995), Gilligan's work has been further researched and resulted in mixed conclusions (Crow et al., 1991).

Many studies have observed the gender differences in ethical sensitivity with females tending to exhibit higher levels of ethical 
orientations (Glover et al., 2002; Loo, 2003; Roxas \& Stoneback, 2004; Albaum \& Peterson, 2006). At the same time, some studies have concluded that there are no significant ethics differences based on gender. Some of the studies were conducted with student samples while others were done with managers in different parts of the world (McCabe et al., 2006). In short, earlier research is inconclusive about the issue of gender differences in moral development or levels of ethical sensitivity. McCuddy and Perry (1996) argue that prior researchers posit only an insignificant relationship between gender and ethical attitudes. According to them, it is illogical to consider any gender inherently being more or less ethical than the other gender. Likewise, Matlin (1993) indicates that most studies support the similarities perspectives, that is, there is no difference between men and women in moral and ethical responses.

In the view of Peterson et al., (2001) reasons behind any gender difference on ethical sensitivity is not clear. Miller and Costello (2001) provide an explanation that points at biological determinism suggesting that gendered behavior is linked to absolute biological roots. As per this theory, the cause of the difference in the ethical behavior between male and female is their biological disposition to act in a particular manner. According to this view, people behave because of biological reasons and social and other environmental causes are inconsequential or negligible (Udry, 2001). But this theory of people being born with ethical dispositions is not very strong or convincing. Other explanations invoked early socialization processes where females, at least in some contexts, are exposed to different interactions with their parents and teachers. The role of socialization especially on the basis of gender in developing ethical system has been acknowledged by research (Stead et al., 1990).

Bampton and Maclagan (2009) point out the tendency of many researchers to rely on conventional statistical measures and arrive at weak or oversimplified conclusions. According to them, there are many significant factors unique to each gender which alone can bring insights to the differences, if at all emerged as the outcome of the research, in the ethical sensitivity among genders. In her work, Carol Gilligan (1993) suggested that women tend to demonstrate an 
'ethics of care', rather than a solely 'justice' or 'rule-based' reasoning which may be more characteristic of men. Her view is not to be misunderstood as women are more ethical than men or vice versa, rather a different approach by each gender to ethical decision-making.

Another interesting finding from the existing literature on gender differences on ethical sensitivity is the distinction between students and professionals. Certain research among students indicates female students being more ethical compared to their male counterparts (Jones \& Gautschi 1988, Ruegger \& King 1992, Whipple \& Swords 1992). However, research among professionals suggests there is no such difference on the basis of gender (Dubinsky \& Levy, 1985; Callan, 1992; Serwinek, 1992). This means that any generalisations on this issue can be a far cry from the reality. Similarly, it poses additional questions on generalisations on the basis of demographics. Bampton and Maclagan (2009) argue that due to the narrow focus of researchers on their preferred functional areas or business sectors, the tool they use tend to reflect this factor and in turn impacts the outcomes of their research and brings a natural bias towards any of the gender. The implication of their study is the importance of using gender-sensitive tools to understand the difference between the genders.

In the light of the mixed results from various studies done across the globe, the following hypothesis is developed to test whether there is any difference in ethical sensitivity across genders in the Indian context.

Null hypothesis: There is no significant difference in ethical sensitivity on the basis of gender differences among management students.

Alternate hypothesis: There is a significant difference in ethical sensitivity on the basis of gender differences among management students.

\section{Methodology}

The study measuring the difference in ethical sensitivity across genders is conducted on the Postgraduate students of various 
business schools. The population is the students from different Business schools in Bangalore. According to the online portal India Study Centre, there are about 100 business schools in Bangalore (www.indiastudycentre.com). The sample for the study is 259 postgraduate students from 5 different business schools in Bangalore. This is about $5 \%$ of the population size. Among the five business schools, two are part of Private Universities; one is an autonomous institution, one is a privately managed Business school, and the final one is an affiliated college of a Public University.

Twenty business-related ethical vignettes are used as the tool to measure the ethical sensitivity of the students. This is an adapted and extended version from the one devised by Longenecker and team for a longitudinal study of the ethical sensitivity of a group of managers in small business (Longenecker, Mckinney, \& Moore, 1989). The scenarios are modified, and four more are added to the original to make them apt and relevant to the Indian environment. The scenarios represent various business situations which any manager or business person would encounter on a day to day basis. It includes issues like embezzlement of the expense report, fraud in different areas of business and similar hypothetical business situations. There are situations of serious unethical concerns as well as ambiguous ones. The rating scale used is a 7 point scale from 1 (not at all acceptable) to 7 (always acceptable). The students have to choose a specific score for each of the situations. The mean score of 20 scenarios would give each student's overall measure of ethical sensitivity.

Anova is employed to measure the overall difference in ethical sensitivity across genders among the participants. T-test used to measure gender differences in individual scenarios measuring ethical sensitivity. The internal consistency of the 20 scenarios in the ethical sensitivity questionnaire is measured using Cronbach's Alpha. 


\section{Results}

Table 1 Gender distribution of the sample

\begin{tabular}{cccc}
\hline Gender & No. distributed & Count & \% of total \\
\hline Male & 160 & 121 & 47 \\
Female & 160 & 138 & 53 \\
Total & 320 & 259 & 100 \\
\hline
\end{tabular}

The number of female respondents (53\%) was slightly higher than male students of the sample. Male respondents constituted the remaining $47 \%$. The response rate of the female students was higher than that of male counterparts as females showed more willingness to participate in the study. While the response rate of male students was $76 \%$, the response rate of female students was about $86 \%$.

\section{Ethical sensitivity and gender}

Table 2 Ethical sensitivity across gender

\begin{tabular}{lcccccc}
\hline & & $\mathbf{N}$ & Mean & Std. Dev & F Score & Sig. \\
\hline $\begin{array}{lcccc}\text { Overall Ethical } \\
\text { Sensitivity }\end{array}$ & Female & 138 & 3.34 & 1.05 & & \\
Score & Male & 121 & 3.71 & 1.06 & 12.15 & 0.00 \\
\hline
\end{tabular}

Table 2 shows the result of the ANOVA analysis measuring the difference in ethical sensitivity across gender. The results show the sigma value as $0.00(\mathrm{p}<0.05)$, and hence the null hypothesis is rejected, and alternate hypothesis is accepted. There is a significant difference in ethical sensitivity between male and female students.

Table 3: Ethical sensitivity difference in individual scenarios across gender

\begin{tabular}{lcccc}
\hline \multicolumn{1}{c}{ Scenarios } & \multicolumn{2}{c}{ Mean } & t-value & \multirow{2}{*}{ Sig. } \\
& male & female & & \\
\hline $\begin{array}{l}\text { An executive earning Rs 50,000 a month } \\
\text { exaggerated his Travel expense account by } \\
\text { about Rs 2,000 which he has spent for his }\end{array}$ & 3.06 & 2.95 & -0.514 & 0.608 \\
$\begin{array}{l}\text { personal needs. } \\
\begin{array}{l}\text { In order to minimize the cost, the HR } \\
\text { department introduced lay off policies for }\end{array}\end{array}$ & & & & \\
$\begin{array}{l}\text { senior employees, at the same time hiring } \\
\text { fresh graduates to meet the labour }\end{array}$ & 3.74 & 3.98 & \multirow{2}{*}{1.059} & 0.291 \\
\begin{tabular}{l} 
requirements \\
\hline
\end{tabular} & & & & \\
\hline
\end{tabular}




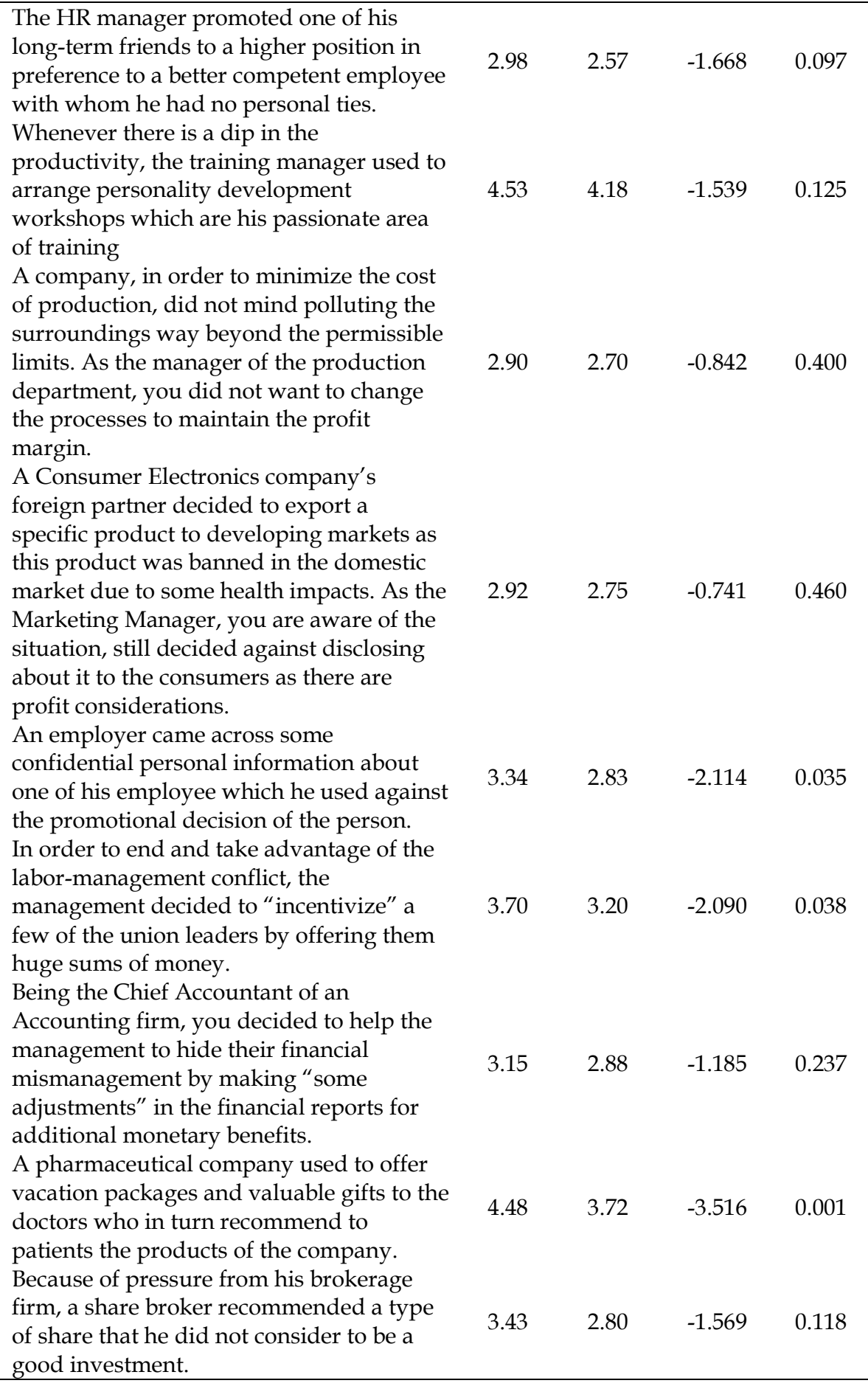




\begin{tabular}{|c|c|c|c|c|}
\hline $\begin{array}{l}\text { A small business received one-fourth of its } \\
\text { gross revenue in the form of cash. The } \\
\text { owner reported only one-half of the cash } \\
\text { receipts for income tax purposes. }\end{array}$ & 3.56 & 3.36 & -0.876 & 0.380 \\
\hline $\begin{array}{l}\text { A company paid Rs } 500,000 \text { "consulting" } \\
\text { fee to an official of a foreign country. In } \\
\text { return, the official promised assistance in } \\
\text { obtaining a contract that will produce Rs } 1 \\
\text { crore profits for the contracting company. }\end{array}$ & 4.30 & 3.84 & -1.997 & 0.047 \\
\hline $\begin{array}{l}\text { A company Chairman found that a } \\
\text { competitor had made an important } \\
\text { scientific discovery, which would sharply } \\
\text { reduce the profits of his own company. He } \\
\text { then hired a key employee of the } \\
\text { competitor in an attempt to learn the } \\
\text { details of the discovery. }\end{array}$ & 4.66 & 4.07 & -2.629 & 0.009 \\
\hline $\begin{array}{l}\text { A corporate director learned that his } \\
\text { company intended to announce a share } \\
\text { split and increase its dividend. On the } \\
\text { basis of this information, he bought } \\
\text { additional shares and sold them at a gain } \\
\text { following the announcement. }\end{array}$ & 3.95 & 3.72 & -0.994 & 0.321 \\
\hline $\begin{array}{l}\text { An engineer discovered what he perceived } \\
\text { to be a product design flaw which } \\
\text { constituted a safety hazard. His company } \\
\text { declined to correct the flaw. The engineer } \\
\text { decided to keep quiet, rather than to take } \\
\text { his complaint outside the company. }\end{array}$ & 3.33 & 3.18 & -0.621 & 0.535 \\
\hline $\begin{array}{l}\text { An employer received an application for a } \\
\text { supervisor's position from two equally } \\
\text { qualified applicants but hired the male } \\
\text { applicant because he thought that some } \\
\text { employees might refuse being supervised } \\
\text { by a female. }\end{array}$ & 3.49 & 2.70 & -3.362 & 0.001 \\
\hline $\begin{array}{l}\text { A cigarette manufacturer launched a } \\
\text { publicity campaign challenging a } \\
\text { campaign by the Ministry of Health office } \\
\text { that cigarette smoking is harmful to the } \\
\text { smoker's health. }\end{array}$ & 3.83 & 3.26 & -2.177 & 0.030 \\
\hline $\begin{array}{l}\text { As part of the marketing strategy for a } \\
\text { product, the producers changed its colour } \\
\text { and marketed it as 'new and improved', } \\
\text { even though its other characteristics were } \\
\text { unchanged. }\end{array}$ & 4.26 & 3.93 & -1.392 & 0.165 \\
\hline $\begin{array}{l}\text { An owner of a small business firm } \\
\text { obtained a free copy of copyrighted } \\
\text { computer software program from a }\end{array}$ & 4.53 & 4.15 & -1.670 & 0.096 \\
\hline
\end{tabular}


business friend rather than spending Rs 5000 to obtain his own program from the software dealer.

The t-test is done to identify whether there is a significant difference between the various ethical scenarios across the genders has produced the above result as mentioned in table 3. Female students have shown greater ethical sensitivity as expressed the mean ethical sensitivity scores. In 19 out 20 ethical scenarios (refer table 3), female students have reported higher sensitivity and in 7 of those scenarios, the difference is statistically significant. This finding is in tune with the many of the earlier research that has reported females exhibiting higher levels of ethical orientation.

\section{Discussion}

The results show a very evident difference in the ethical sensitivity across different genders. In 19 out of 20 vignettes, female students reported greater sensitivity towards ethical scenarios. The scenarios represent different possible unethical situations varying from dishonest behaviour for personal benefits to breach of trust and gross indifference towards people and environment. There are seven vignettes where there is a statistically significant difference in the way female students responded as against their male counterparts showing greater ethical sensitivity. Those seven vignettes are presented here along with short discussion about each situation.

Vignette 1: An employer came across some confidential personal information about one of his employee which he used against the promotional decision of the person.

The scenario represents a breach of confidentiality and privacy in a relationship. Female students, in general, find this situation more unacceptable which may be considered as an expression of their care orientation. From a business point of view, the action of the employer may be justified considering the overall benefit for the organisation. But from the affected party's perspective, it might be viewed as an intrusion into privacy and victimizing using the private personal information. Female students in general feel for 
the affected party as an implicit expression of greater care orientation. It may be hypothesized that differences between male and female ethics are more marked when issues inviting a 'care' orientation are involved.

Vignette 2: In order to end and take advantage of the labormanagement conflict, the management decided to "incentivize" a few of the union leaders by offering them huge sums of money.

Given the analysis from the previous scenario that females would demonstrate more 'care' than men, this scenario presents a concern for the victimised laborers. By bribing the union leaders, management tries to 'solve' the labour-management conflict making the invisible laborers as losers. Here again, the care orientation of female students expresses this as unacceptable whereas 'business-oriented, impersonal' values of male students more tolerant towards it.

Vignette 3: A pharmaceutical company used to offer vacation packages and valuable gifts to the doctors who in turn recommend to patients the products of the company.

This vignette presents the unethical, yet the widely practised issue of 'giving gifts' to the doctors in the medical fields to influence their prescription to the benefit of the concerned pharma company. Here again, though the key stakeholders are a company, its representatives and doctors, the consequence is felt primarily by the patients. A similar situation of victimization is played out, and female students consider more unacceptable than their male counterparts because of their higher care orientation.

Vignette 4: A company paid Rs 500,000 "consulting" fee to an official of a foreign country. In return, the official promised assistance in obtaining a contract that will produce Rs 1 crore profits for the contracting company.

This scenario is a clear act of accepting bribery for receiving a favour, most likely an undeserving favour. In other words, it's an attitude of accepting or engaging by any means to achieve a favorable outcome or end. Here again, men are more comfortable in such an approach compared to women. 
Vignette 5: A company Chairman found that a competitor had made an important scientific discovery, which would sharply reduce the profits of his own company. He then hired a key employee of the competitor in an attempt to learn the details of the discovery.

Several ethical issues are involved here like poaching, confidentiality breach, dishonesty etc. many a time, people engage in ethical violations as they don't perceive issues as an ethical issue, rather a business problem. This is a kind of motivated blindness or inability to discern the ethical aspect of the business situation. Female gender seems to have greater sensibility towards the 'ethical' aspect of situations whereas the ethical dimension is more blurred for men and in many cases, it fades into the non-existence.

Vignette 6: An employer received an application for a supervisor's position from two equally qualified applicants but hired the male applicant because he thought that some employees might refuse being supervised by a female.

The above case is a situation of gross gender discrimination. Though most companies harp about gender equality and include them in the code of ethics, there might be various implicit and inherent practices in the company that goes against gender equality. Obviously, the female students express the unacceptability of such a scenario.

Vignette 7: A cigarette manufacturer launched a publicity campaign challenging a campaign by the Ministry of Health office that cigarette smoking is harmful to the smoker's health.

The action of the company indicates their callous attitude towards the health of people. Undivided focus on profit at the cost of injury to others is unethical capitalism which cannot be acceptable in a just and caring society. As in the previous cases, female students are more sensitive towards the issues causing injury to individuals.

The above vignettes and subsequent analysis show there is an obvious difference in the way of approaching ethical issues in terms of gender. While men are comfortable with an impersonal, result-oriented, business-focused approach, women have a more relationship, personal and care-oriented approach to ethical issues. 
The findings here are consistent with the understanding of care ethics proposed by Gilligan (1993) and Noddings (2003) in their exploration of how female moral thinking differ from that of men.

\section{Conclusion}

Gender difference in ethical sensitivity with females tending to be more ethically oriented than their male counterparts is observed in this study. In 19 out of 20 vignettes female students reported higher ethical sensitivity expressing greater unacceptability of various unethical business situations and issues, rejecting the null hypothesis of the study that there is no significant difference in ethical sensitivity across gender. It is found that women judge situations quite differently from men especially when a "care orientation" is involved. The findings also show that men are more tolerant to unethical situations when impersonal values of profit and business are involved. As Bampton and Maclagan (2009) observe, "for male students 'acceptable business practice' mean 'profitable' in a narrow commercial sense, rather than 'ethical' in the sense that a wider range of stakeholders is 'cared' for."

The finding of gender differences in ethical sensitivity needs further investigation as the sample used in the study is restricted to business students and data is reliant on self-reporting. Analysis of professionals in the field can give a deeper perspective on the theme and should be considered for further future research. It would be interesting to see the differences in the perception between the aspiring managers who merely visualises possible ethical scenarios and those who are actually in the corporate and facing the ethical dilemmas.

\section{References}

Bampton, R., \& Maclagan, P. (2009). Does a 'care orientation' explain gender differences in ethical decision making? A critical analysis and fresh findings. Business Ethics: A European Review, 18 (2), 179 - 192.

Burns, C., \& Krehely, J. (2013, June 2). Gay and Transgender People Face High Rates of Workplace Discrimination and Harassment. Retrieved October 18, 2013, from americanprogress.org: http:// www.americanprogress.org/ issues/ 
Choudhary, C. (2011, July 27). 20 years later, India's transition is incomplete. Retrieved from Blooberg.com: http://www.bloomberg.com/ news/ 2011-07-26/20-years-later-india-s-transformation-is-incompleteworld-view.html

Gilligan, C. (1993). In a Different Voice: Psychological Theory and Women's Development. Cambridge, MA: Harvard University Press.

Kray, L., Kennedy, J., \& Ku, G. (2017, March 8). Are women more ethical than men? Retrieved from Greater Good Magazine: https:// greatergood.berkeley.edu/article/item/are_women_more_ethical_th an_men

Longenecker, J. G., Mckinney, J. A., \& Moore, C. W. (1989). Ethics in small business. Journal of Small Business Management, 27 - 31.

Noddings, N. (2003). Caring: A Feminine Approach to Ethics and Moral Education, 2nd edition. Berkeley, CA: University of California Press.

Pal, A. (2012, May). Dark side of India's success. Retrieved October 18, 2013, from http://progressive.org/dark_side_of_india_s_success.html

Pianin, E. (2017, May 23). Data shows millennial women are dominating the current job market. Retrieved October 18, 2013, from Inc.com: https://www.inc.com/the-fiscal-times/millennial-women-dominatejob-market-men-overshadowed.html

Wen, T. (2013, August 23). Do female CEOs behave more ethically? Retrieved October 18, 2013, from dailybeast.com: http:// www.thedailybeast.com/witw/articles/2013/08/23/where-are-allthe-scandals-involving-female-ceos.html

Wolfe, L. (2017, September 11). Unequal pay is a form of gender discrimination. Retrieved from thebalance.com: https:// www.thebalance.com/gender-discrimination-in-the-workplace3515145 